2014-01-02

\title{
Linking research and teaching: context, conflict and complementarity
}

\section{Pan, W}

http://hdl.handle.net/10026.1/5715

10.1080/14703297.2013.847794

Innovations in Education and Teaching International

Informa UK Limited

All content in PEARL is protected by copyright law. Author manuscripts are made available in accordance with publisher policies. Please cite only the published version using the details provided on the item record or document. In the absence of an open licence (e.g. Creative Commons), permissions for further reuse of content should be sought from the publisher or author. 
This is an Accepted Manuscript of an article published by Taylor and Francis in Innovations in Education and Teaching International, available at:

http://www.tandfonline.com/doi/abs/10.1080/14703297.2013.847794?journalCode=riie20

\title{
Linking research and teaching: context, conflict and complementarity
}

\begin{abstract}
Although research and teaching have been regarded complementary in enhancing the quality of student learning, little previous research has explored the conflicts associated with linking the two activities. This controversial relationship is compounded by profound differences across contexts of learning. This paper aims to examine such conflicts and complementarities and explore strategies for achieving optimal research-teaching linkages. The research was carried out using a case study with the environmental building disciplines at a university in the UK. The results reveal that the research-teaching linkages in the disciplines were interrelated and dynamic and the practice of linking the two was controversial, evidenced in the coexisting multifaceted conflicts and complementarities. A number of strategies are provided for achieving optimal research-teaching linkages. It is critical to systematically link research and teaching cross the entire educational programme, to address the progressive nature of learning, the interrelated dynamic researchteaching linkages and their associated multiple stakeholders.
\end{abstract}

Keywords: research-teaching nexus; research-teaching linkage; environmental building; sustainable construction; learning process 
This is an Accepted Manuscript of an article published by Taylor and Francis in Innovations in Education and Teaching International, available at:

http://www.tandfonline.com/doi/abs/10.1080/14703297.2013.847794?journalCode=riie20

\section{Introduction}

Linking research and teaching is increasingly regarded as an effective approach to enhancing the quality of student learning in higher education (see e.g. Brown and McCartney 1998; Jenkins et al. 2007). In a House of Commons (2009:77) report, the relationship between research and teaching was described as being of crucial importance:

'It highlights a serious and fundamental question about the nature of a 'university education', the distribution of excellence and the relative roles of teaching, research and scholarship in supporting student learning, not least in terms of developing students' professional and learning skills.'

However, although research and teaching have been considered complementary, insufficient attention in the literature has been paid to the conflicts associated with linking the two activities. Previous research has examined the 'disadvantages' and the 'barriers' of the research-teaching nexus (Healey et al. 2010 and Buckley 2011, respectively).

However, the conflicts of linking research and teaching have seldom been made explicit in previous research, which runs a risk of rendering the approach of linking research and teaching less effective.

Furthermore, the controversial relationship between research and teaching is compounded by profound differences across contexts of learning in different disciplines and fields of study. Griffiths (2004) suggested that such differences include the nature of the knowledge base, the drivers behind discipline development, the processes governing curriculum design, the dominant methods of teaching and assessment and the way academic staff are recruited, and therefore urged that the features of built environment disciplines, and of 
This is an Accepted Manuscript of an article published by Taylor and Francis in Innovations in Education and Teaching International, available at:

http://www.tandfonline.com/doi/abs/10.1080/14703297.2013.847794?journalCode=riie20

other practice-oriented fields, should be considered for bringing together knowledge

production and student learning. Durning and Jenkins (2005) supported that view by

providing evidence to show that in built environment disciplines there are distinct features

of research-teaching relations that need to be taken account of in departmental policies and

national funding. Following that, some other researchers advocated that student learning

can be supported through enhanced links between research and teaching in specific built

environment disciplines, e.g. in architecture (Roberts 2007) and building and surveying

(Deakin 2006). However, few studies to date have investigated the context, conflict and

complementarity of linking research and teaching in the disciplines of environmental

building and sustainable construction. This gap in knowledge is considered significant as

sustainable building and construction has been promoted in many countries as an effective

approach to reducing the impact of building and construction on human health and the

environment (see the United Nations Environment Programme (Cheng et al. 2008)). In the

UK, sustainable construction has been specifically highlighted as strategically important

for the future of the construction industry (BERR 2008). However, the embedding of

sustainability in higher education has been far from straightforward and highly problematic

(Cotton and Alcock 2012). Therefore, this paper aims to address the environmental

building and sustainable construction disciplines by examining the conflicts and

complementarities of linking research and teaching. The paper first evaluates the current

research-teaching nexus in the selected disciplines, then examines the conflicts and

complementarities associated with linking research and teaching, and finally explores how

optimal research-teaching linkages can be achieved. 
This is an Accepted Manuscript of an article published by Taylor and Francis in Innovations in Education and Teaching International, available at:

http://www.tandfonline.com/doi/abs/10.1080/14703297.2013.847794?journalCode=riie20

\section{The research-teaching linkages}

The interpretations of the concepts 'research' and 'teaching' have long been contested. In this paper, the term 'research' denotes discipline-specific research by staff and the term 'teaching' indicates undergraduate teaching specifically. Postgraduate teaching and supervision are undoubtedly more intimately connected to staff research and are not covered in this paper. Also, the terms to classify or describe the research-teaching nexus vary, albeit with subtle differences and being actually often used interchangeably. A typical classification of the research-teaching nexus was developed by Griffiths (2004), which includes four approaches:

- Research-led teaching - where students are taught about research findings (the lecturer's own and those of other researchers);

- Research-oriented teaching - where students are taught about research processes and methods;

- Research-based teaching - where students undertake research activities, or inquirybased learning approaches;

- Research-informed teaching - which involves inquiry into the process of teaching and learning (pedagogic research).

This model was extended further by Healey (2005), who mapped curriculum design against the research-teaching nexus according to the students' roles as participants or audience and learning emphasis on research content or processes. Healey omitted 'research-informed teaching', but incorporated a new approach, entitled 'research-tutored', which entailed students engaging in discussions around research issues. Taking these two 
This is an Accepted Manuscript of an article published by Taylor and Francis in Innovations in Education and Teaching International, available at:

http://www.tandfonline.com/doi/abs/10.1080/14703297.2013.847794?journalCode=riie20

widely-acknowledged models together, the five types of research-teaching nexus outlined above are used for the examination reported in this paper.

\section{Research method}

This research was guided by the case study principles in which to provide an in-depth and analytical account of the unit of analysis (Yin 2003), which was the research-teaching nexus in the environmental building and sustainable construction disciplines. The case study was carried out at a new university in the UK, an institution with some 30,000 students and 3000 staff. This university was a former polytechnic and was given university status in 1992. The university has developed a strong research profile in many areas, and offers a broad curriculum of which there are a large range of professional courses. The university received significant funding for projects supporting the research-teaching nexus between 2007 and 2009, and at a policy level these links have been embedded into the institution's teaching, learning and research strategies. The case study approach with post1992 universities was also used in previous research on the research-teaching nexus (e.g. Durning and Jenkins 2005; Healey et al. 2010). Generalisability is understood in terms of Hammersley 's (1998) 'theoretical inference', whereby conclusions move from the specific to the wider conceptual level, drawing on extant theory and previous research findings. Such generalisation should follow a 'replication logic' (Yin 2003).

Under the banner of the case study design, this research employed multiple research methods including: a literature review; a desk study of the research-teaching nexus in the case disciplines and university; semi-structured interviews with all the academics in the disciplines (nine in total homed in the Environmental Building Group); semi-structured individual interviews with six recent graduates; and a focus group with six final-year 
This is an Accepted Manuscript of an article published by Taylor and Francis in Innovations in Education and Teaching International, available at:

http://www.tandfonline.com/doi/abs/10.1080/14703297.2013.847794?journalCode=riie20

students. The adoption of the multiple research methods aimed to enable triangulation of results (Bryman 2008). The group of academics consisted some who were highly researchactive, some with very successful teaching-focused careers and pedagogic research expertise, and some who were recruited on the basis of their strong industrial experience. The selection of the graduates and students for the study was guided by a stratified sampling strategy to ensure that the learner participants together covered all the three programmes in the case disciplines. These programmes were: Building Surveying and the Environment, Construction Management and the Environment, and Environmental Construction Surveying. All these programmes consisted three years of university-based study (First, Second and Fourth (Final) Years) and an optional industry-based placement (Third Year), and were accredited by relevant professional bodies and therefore had a strongly professional remit.

All the interviews covered the topics including the practice of linking research and teaching, conflicts and complementarities of such linkages, and strategies for achieving optimal linkages. All interviewees were provided with definitions and explanations of the five types of research-teaching nexus to help illustrate and therefore improve the effectiveness of the interviews. Each interview took between 45 minutes and an hour. The interviews and the focus group were audio-recorded, and the recordings were transcribed for analysis. The academics were asked to assess and provide evidence about the nature and frequency of the research-teaching nexus occurring in their taught modules. The frequency was measured using a five-point Likert scale, consisting 'never', 'seldom' (e.g. once a term), 'sometimes' (e.g. once a month), 'often' (e.g. once a week) and 'always'. The qualitative data was analysed through a thematic approach, using the constant 
This is an Accepted Manuscript of an article published by Taylor and Francis in Innovations in Education and Teaching International, available at:

http://www.tandfonline.com/doi/abs/10.1080/14703297.2013.847794?journalCode=riie20

comparative method to draw out similarities and differences between the responses

(Strauss and Corbin 1998). The data was used to theorise about the research-teaching nexus in environmental building and sustainable construction education. 
This is an Accepted Manuscript of an article published by Taylor and Francis in Innovations in Education and Teaching International, available at:

http://www.tandfonline.com/doi/abs/10.1080/14703297.2013.847794?journalCode=riie20

\section{Results and analysis}

\section{The practice of linking research and teaching}

The research-teaching linkages in the practice were assessed in terms of their nature (i.e. what type(s) of nexus) and frequency of application. The key findings include:

- All the academics linked research with teaching, albeit to varied extents. The researchteaching nexus was embedded in the educational practice of the academic group across all the three university-based years of study.

- The linkages between research and teaching became more frequent from Year 1 to the Final Year. There was also a notable increase of the use of the more student-centred approaches (particularly research-oriented teaching) in the Final Year (even disregarding the dissertation to enable a fairer comparison).

- Research-led teaching was applied in all the years; research-based teaching and research-tutored teaching were more heavily applied in the Final Year, and somewhat in Year 2. Research-oriented teaching was more frequent in Year 2. Research-informed teaching (i.e. pedagogic research) was comparatively less practiced in Year 2 and the Final Year than the other research-teaching links.

- It was generally perceived to be difficult to categorise research-teaching links in practice, using the provided research-teaching nexus (i.e. developed by Griffiths 2004 and Healey 2005). The respondents commented that the educational practice sometimes involved more than one research-teaching linkage, and therefore felt that the research-teaching linkages were interrelated and difficult to be assessed in an isolated manner. 
This is an Accepted Manuscript of an article published by Taylor and Francis in Innovations in Education and Teaching International, available at:

http://www.tandfonline.com/doi/abs/10.1080/14703297.2013.847794?journalCode=riie20

- Although the research-teaching linkages were commonly described, the practices of linking the two were implicit in many cases. The group lacked an established strategy for implementing these linkages across the disciplines.

\section{Complementarities of linking research and teaching}

The results suggest that research and teaching in the environmental building and sustainable construction disciplines were complementary.

The research-teaching linkages were considered to have enhanced student employability in the disciplines. The interviewees generally agreed that student employability could be enhanced via improved critical thinking skills and practical skills at handling real-life cases, which could be developed by research. One academic suggested that:

'research strongly linked to industry-wide problems could be used to raise the profile of the lecturers and the students both through reputational benefits and specific skills developed.'

Also, the research-teaching linkages were perceived to have contributed to the pursuit of excellence in teaching and learning of both lecturers and students. A desire for new and up-to-date information in teaching and learning was found amongst both the lecturers (who wanted to convey the latest findings of research) and the students (who expected to receive the newest information). The staff participants also noted the importance of going beyond the textbook to nurture student development; for example, one professor commented that: 
This is an Accepted Manuscript of an article published by Taylor and Francis in Innovations in Education and Teaching International, available at:

http://www.tandfonline.com/doi/abs/10.1080/14703297.2013.847794?journalCode=riie20

'Textbook teaching must be complemented by scholarly research resources; we

need to encourage students to read academic publications and develop scholarly attitudes to their learning.'

The pedagogic research undertaken by the group was felt to complement the disciplinespecific research in building science, engineering and management, opening a window of opportunity for bridging research and teaching.

Furthermore, the research-teaching linkages were regarded beneficial to the pursuit of excellence in research as well as the rapidly growing research profile of the group, although this complementarity was less frequently cited and somewhat contested. The group had a strong desire to enhance research activity for the Research Excellence Framework (REF) 2014, an exercise crucial to the reputation of UK institutions and academics (see http://www.hefce.ac.uk/research/ref/). Most staff considered themselves research active, and their enthusiasm for research was translated in teaching as a desire to help students develop their critical thinking skills.

\section{Conflicts of linking research and teaching}

Conflicts were also revealed of linking research and teaching. These conflicts were found existed at the institutional, industry, university, discipline and individual levels.

Time conflicts were identified by the academics in their practice of linking research and teaching. The time conflicts were primarily reflected in the perceived over-crowding of the curriculum and the difficulty of maintaining a balance between different aspects of the academic role, e.g. research and teaching. Although some staff could see potential benefits 
This is an Accepted Manuscript of an article published by Taylor and Francis in Innovations in Education and Teaching International, available at:

http://www.tandfonline.com/doi/abs/10.1080/14703297.2013.847794?journalCode=riie20

from linking research and teaching, others regarded such practice as an additional element

to be added to the curriculum, or viewed research and teaching as being in competition:

"There is no practical reason to link research with teaching, if the challenge of time means that you can not do either well”.

The time conflicts were found to be, at least partly, grounded on the different aspirations of the academics regarding research and teaching. Some staff perceived that teaching was more bound to professional obligation (what academics were paid to do, and therefore had to do), while research appeared to be more closely associated with academic desirability (what academics wanted to do) and with career progression. Nevertheless, despite the conflicting perceptions, one interviewee commented that the dynamic combination of the different skills, expertise and background of the academics in the group (i.e. covering discipline and pedagogic researchers, as well as professionals from industry) offered students an excellent balance of learning experiences.

Also, conflicts were suggested existing between the academic and the professional/ vocational aspects of learning in the disciplines. There was a tension between 'education about building' and 'education for building', which was perceived to be critical to achieving optimal linkages of research and teaching. 'Education about building' denotes a form of education that is largely scientific and research-focused, while 'education for building' refers to the more practical elements. Ambivalence about the value of research appeared not only among academics but also students. Both groups argued that there should be a balance between critical scholarly thinking and vocational real-life teaching. Questions were raised about whether the disciplines should be research-led and take a more holistic, academic approach, or be market-led and therefore prioritise the needs of 
This is an Accepted Manuscript of an article published by Taylor and Francis in Innovations in Education and Teaching International, available at:

http://www.tandfonline.com/doi/abs/10.1080/14703297.2013.847794?journalCode=riie20

industry. To add to the complexity, all the three programmes studied were accredited by

professional bodies, which together with quality assurance requirements imposed a strong influence on many aspects of teaching and learning including student selection, curriculum design and pedagogies, teaching quality and assessments. However, the research-teaching nexus are not specifically required by professional bodies. Several academics perceived the influence of professional bodies as excessive, and leading to (too) prescriptive courses.

In addition, conflicts were considered existing between the promotion and support for linking research and teaching at the institutional level and the dearth of detailed guidance on such linkages at the discipline level. This conflict partly explains the awareness of, but insufficient or inconsistent understanding of, the research-teaching nexus that was identified among both academics and students. Two academics also commented that the generally recognised research-teaching models (e.g. Healey 2005) mislead by separating the research-teaching linkages which in practice are interwoven. As an example, one academic noted:

"The "Sustainable and Safe Construction" coursework is on $100 \%$ assessment (research-oriented and research-based); however, the lectures are research-led (often) and research-tutorial (sometimes).'

Moreover, conflicts were identified of the academics with different levels of researchactiveness. Although changing rapidly, some academics were perceived as not research active, and therefore unable to contribute effectively to optimal research-teaching linkages:

'I think we need to rethink our recruitment, of not only students but also staff. Currently, some members of staff are polytechnic-minded, conducting textbook- 
This is an Accepted Manuscript of an article published by Taylor and Francis in Innovations in Education and Teaching International, available at:

http://www.tandfonline.com/doi/abs/10.1080/14703297.2013.847794?journalCode=riie20

based teaching and locked in vocational education mindset. We will need more research-active staff, in order to change our graduates' profile.'

However, it should also be noted that some staff identified the burgeoning research profile of the group as inhibiting the achievement of optimal research-teaching linkages due to time conflicts between research and teaching. One academic noted:

'Our first job should be to produce a good stock of students for high-quality employers, rather than the advancement of personal research interests/profile.'

Another interviewee explained the tension between research and teaching by adding that:

'There is a fragmented research culture in the group, with academics carrying on research on an individual basis.'

Furthermore, conflicts of logistics and facilities of university education were noted, which adversely impact on enhancing the research-teaching linkages. An example was large class sizes that were seen by some academics as limiting the possibilities for teaching innovation. One academic commented that:

'I tried to encourage students' critical thinking by asking them challenging questions, but found it was difficult to engage students in big groups, e.g. 70 in Year 1 and 50 in Year 2.'

Another academic referred to a similar experience, in which he was unable to check whether students had completed research work set owing to the large class size. These comments were confirmed by the students interviewed, who preferred smaller class sizes in general, and suggested maximum 6 to 10 for research-tutored sessions to make their learning effective. Another example was student instrumentalism that was noted by the academic staff. One interviewee commented that: 
This is an Accepted Manuscript of an article published by Taylor and Francis in Innovations in Education and Teaching International, available at:

http://www.tandfonline.com/doi/abs/10.1080/14703297.2013.847794?journalCode=riie20

'Students were concerned about whether it would help with exams or lead to better marks only, but not interested in research-teaching links and participating in research-informed teaching.'

A further example was the lengthy institutional quality assurance processes required for seeking approval for changes and revisions to courses.

\section{Strategies for achieving optimal research-teaching linkages}

A number of strategies for achieving optimal research-teaching linkages were identified:

- Improving communications within and beyond the disciplines about research and teaching. Many academics were unaware of the university-level policies and practices; even communications within the group were limited. The confusion about the definition of 'research' was also noted.

- Building the research-teaching nexus into the curriculum at all the stages of the university learning. Research practices could be shared with students from first attendance at 'Open Days', and research-teaching linkages embedded throughout the programme. In the Final Year, research should be promoted as a future career path, while the dissertation acts as a 'capstone' project.

- Producing a guide for linking research and teaching within the disciplines, with case studies of good practice. This guide should balance detailed procedures and generic guidance, and take into account staff, discipline and course specifics, linking the research-teaching nexus with the development of real-life skills such as problem solving, communication and critical analysis. The students desired 'hard' data, authentic information and research methods that they could use to develop their own 
This is an Accepted Manuscript of an article published by Taylor and Francis in Innovations in Education and Teaching International, available at:

http://www.tandfonline.com/doi/abs/10.1080/14703297.2013.847794?journalCode=riie20

arguments, rather than being taught others' opinions. These skills were perceived by students as important to their future career.

- Emphasising the importance of teaching excellence in staff assessment and appointment. It was argued that this would encourage staff to take the researchteaching nexus more seriously, and help avoid a clear split between research and teaching in wider academic life.

- Enhancing the use of active learning approaches. The students realised the significance of research findings, but also highlighted the importance of maintaining student attention and interest. In particular, more targeted site visits and field trips were requested to help develop hands-on knowledge.

However, it should be noted that the learners identified a need for a balanced pedagogic approach including traditional educational approaches (perceived as didactic, one-way knowledge transfer) and interactive delivery of learning, which inspires enthusiasm and develops understanding. Also, some staff believed that fully integrated research and teaching might not be desirable or appropriate at undergraduate level. Some interviewees argued that it was difficult to synchronise research and teaching fully, given the nature of research as dynamic and fast-moving, so teaching might not be able to keep pace.

\section{Discussion}

A key finding from this study is the co-existing conflicts and complementarities of linking research and teaching in the environmental building and sustainable construction disciplines studied. Underlying the co-existence of the conflicts and complementarities were different perceptions of the concepts 'research' and 'teaching' as well as the varied 
This is an Accepted Manuscript of an article published by Taylor and Francis in Innovations in Education and Teaching International, available at:

http://www.tandfonline.com/doi/abs/10.1080/14703297.2013.847794?journalCode=riie20

aspirations for research-teaching linkages among academics and learners. The researchteaching linkages were perceived as being driven by individual lecturers who were active researchers as well as being responsible for frontline teaching and learning. This had the advantage of enabling research-active staff to embed cutting-edge research into their teaching. However, there was also a perceived trade-off between the time committed to research and teaching activities, hence staff involved heavily in research activities might not be spending enough time on their teaching, or might not be sufficiently aware of industry standards and professional practices. It was also clear that not all staff had the appropriate skills to be engaged in research. Moreover, the learners identified research-led approaches (which are most reliant on staff research activity) as being the least useful type of research-teaching link. The more active approaches, involving students as participants including techniques such as enquiry-based learning in which the students acted as researchers - were open to a wider range of staff and therefore were of clear benefit to teaching. In this sense, it is clear that simplified statistical correlation studies and/or hypothesised claims at an individual level, such as 'the best teaching and learning is led by the best researchers provided that they are appropriately trained to teach' (Cooke 1998), will not satisfactorily address the nature of the research-teaching linkages analysed in this paper. Arguably, it is not essential for all individual staff to excel at all activities, but within a department there should be a balance of skills and an over-riding focus on student involvement in all aspects. Alternatively, it is possible that the optimal situation is staff who have at least a minimal involvement in research, thus accruing identified benefits to teaching without requiring the time commitment of a truly excellent research career. However, the issues of (limited) reward and recognition which would arise for staff taking on this role would not be easy to resolve. 
This is an Accepted Manuscript of an article published by Taylor and Francis in Innovations in Education and Teaching International, available at:

http://www.tandfonline.com/doi/abs/10.1080/14703297.2013.847794?journalCode=riie20

A second interesting finding is the extent of the belief on the time conflict for enhancing research-teaching linkages in the curriculum. This reveals a significant and persistent misunderstanding of the research-teaching nexus that embedding research in the curriculum is often viewed as an add-on, rather than a difference in approach to teaching and learning of the discipline. There was a mixed level of understanding of the researchteaching nexus amongst the lecturers and learners, despite strong university promotion of this agenda. This inconsistent understanding may be attributed to that the researchteaching nexus being encouraged at the policy level lacks detailed guidance on the ways in which these approaches can be implemented in specific disciplines. This indicates that further work needs to be undertaken, preferably through collaboration between academic developers and experienced staff in the disciplines. Such collaboration would enable guidance for future developments whilst taking account of the context and the limitations imposed by professional bodies. The identified conflicts associated with professional accreditation of the programmes echo the findings of previous studies in the built environment (ACBEE 2006). Notably, although ACBEE (2006) promoted the need for university programmes to align with current industry themes and exemplify partnerships, none of their KPIs were directly related to research or research-teaching linkages. Therefore, the industry/professional body influence reflected in 'curriculum creep' (Webster 2002) or 'content coverage mentality' (Griffiths 2004) may have inhibited more research-led and oriented teaching.

A further useful finding is that the rationale for linking research and teaching needs to be clear and explicitly linked to student future employability in professional/vocational 
This is an Accepted Manuscript of an article published by Taylor and Francis in Innovations in Education and Teaching International, available at:

http://www.tandfonline.com/doi/abs/10.1080/14703297.2013.847794?journalCode=riie20

disciplines. This is vital to get buy-in from staff and students on the programmes, and the link with critical thinking appears to be a crucial mediating concept (Pan and Allison 2010). Teaching and learning in building is complex and multi-disciplinary, sharing features of a range of other disciplines, such as science and engineering, humanities and social science, and business and management (Fry et al. 2003). The question raised by Tolley (1983) about the underlying concerns of staff and students in business education, i.e. a study of business or a study for business - such 'for-about spectrum' dichotomy - also exists in building education. This is reflected as a paradox of education for building and education about building. Both aspects are clearly important, and perhaps the aim of a really successful programme would be to integrate the two approaches effectively.

Underlying the conflicts of different perceptions of and aspirations for linking research and teaching is the lack of status of teaching and pedagogic research, which represents a fundamental issue contributing to the long-running and vigorous debate (see VisserWijnreen et al. 2009). It was, and still appears to be, research performance from which many academics obtain their professional identity and are judged by their peers, with teaching accomplishments remaining secondary. Therefore, it is important to renew the interpretation of these two conceptions and the associated reward systems, which will help nurture a paradigm shift of academic attention and efforts towards better integration of research and teaching. Until parity between research and teaching is achieved, there will always be a temptation for academics to focus on research at the expense of good teaching quality. The disciplines studied in this paper included experts in both teaching and research, and it could be argued (as Barnett 1990 did) that these are different kinds of activities and require different skills. However, if reward systems included recognition of 
This is an Accepted Manuscript of an article published by Taylor and Francis in Innovations in Education and Teaching International, available at:

http://www.tandfonline.com/doi/abs/10.1080/14703297.2013.847794?journalCode=riie20

effective integration of research and teaching, rather than a narrowly conceived excellence in one or other (usually research), there would be a much stronger driver for linking research and teaching in all disciplines. This was acknowledged in previous research (Barnett 1990; Jenkins et al. 1998; Brew 2003; Young 2006) - yet there is little evidence of major progress in this area.

Finally, it is clear from this study that the research-teaching linkages were observed as interrelated and dynamic. This echoes the suggestion by Grant and Wakelin (2009) that learning is co-related and co-construed and not just simply consumed by students or offered by academics, and that academics should apply a process view to the nexus to enhance their teaching. This finding also supports the conclusion by Buckley (2011) that some aspects of the research-teaching nexus need to be given particular attention throughout the curriculum in a longitudinal and gradual way. Therefore, the practice of linking research and teaching should be planned and implemented systemically within the whole educational programme to address learning objectives for specific stages of learning. Jonassen (1991) argued that the constructivist-based approach (with which research-based teaching and research-tutored teaching are more associated) is the most effective for the advanced stage of knowledge acquisition. From constructivists' viewpoint, learners are expected to manage their own learning, but this may cause introductory level students frustration and discomfort. The research and teaching linkages should therefore be utilised systemically within the specific context and stage to address the progressive nature of learning.

\section{Conclusions}


This is an Accepted Manuscript of an article published by Taylor and Francis in Innovations in Education and Teaching International, available at:

http://www.tandfonline.com/doi/abs/10.1080/14703297.2013.847794?journalCode=riie20

This paper has examined the practice of linking research and teaching and its associated conflicts and complementarities within the context of the environmental building and sustainable construction disciplines. The results reveal that the research-teaching linkages observed in the disciplines covered all the five types of nexus that are widely recognised in the literature (i.e. research-led, research-based, research-oriented, research-informed, and research-tutored). Also, these linkages were found interrelated and dynamic in the educational practice studied. This practice suggests the controversial nature of the research-teaching nexus, which was evidenced in the co-existing conflicts and complementarities uncovered through the research. On the one hand, the research-teaching linkages were considered to have enhanced student employability, and to have contributed to the pursuit of excellence in teaching and learning of both lecturers and learners, and of excellence in research in the disciplines. On the other hand, the practice of linking research and teaching was perceived to have led to conflicts: over time, e.g. staff time allocated for research and for teaching; between the academic and the professional/vocational aspects of learning; between the promotion of research-teaching linkages at the institutional level and the lack of detailed guidance at the discipline level; between the academics with different levels of research-activeness; and over logistics and facilities for university education.

Although this research was carried out with academics and learners, the observed conflicts and complementarities of linking research and teaching suggest significant influence on student learning of multiple stakeholders that also include those from industry (e.g. employers), professional bodies, and the university beyond the disciplines. Acknowledging the different perceptions of research and teaching and varied aspirations for linking the two among the lecturers and learners, it is important to improve communications within and 
This is an Accepted Manuscript of an article published by Taylor and Francis in Innovations in Education and Teaching International, available at:

http://www.tandfonline.com/doi/abs/10.1080/14703297.2013.847794?journalCode=riie20

beyond the disciplines and to emphasise the importance of teaching excellence in staff assessment and appointment, for achieving optimal research-teaching linkages. Also, it is critical to systematically plan and implement the research-teaching linkages cross the entire learning programme, to address the progressive learning, interrelated dynamic research-teaching linkages and their associated multiple stakeholders. These findings should also inform future practice of linking research and teaching in other practiceoriented fields.

\section{References}

ACBEE (2006) Accelerating Change in Built Environment Education (ACBEE), Report on Phase 3, www.acbee.org.

Barnett, R. (1990) The Idea of Higher Education, Buckingham: The Society for Research into Higher Education/Open University Press.

BERR (2008) Strategy for Sustainable Construction. London: Department for Business, Enterprise and Regulatory Reform (BERR).

Brew, A. (2003) Teaching and Research: New relationships and their implications for inquiry-based teaching and learning in higher education. Higher Education Research \& Development, 22(1), 3-18.

Brown, R.B. and McCartney, S. (1998) The link between research and teaching: Its purpose and implications. Innovations in Education and Teaching International, 35(2), 117-29.

Bryman, A. (2008) Social Research Methods. 3rd edn. Oxford University Press, Oxford.

Buckley, C.A. (2011) Student and staff perceptions of the research-teaching nexus. Innovations in Education and Teaching International, 48(3), 313-22.

Cheng, C., Pouffary, S., Svenningsen, N., Callaway, M. (2008) The Kyoto Protocol, The Clean Development Mechanism and the Building and Construction Sector - A Report for the UNEP Sustainable Buildings and Construction Initiative, United Nations Environment Programme, Paris, France.

Cooke, R. (1998) Enhancing teaching quality. Journal of Geography in Higher Education, 22(3), 283-284. 
This is an Accepted Manuscript of an article published by Taylor and Francis in Innovations in Education and Teaching International, available at:

http://www.tandfonline.com/doi/abs/10.1080/14703297.2013.847794?journalCode=riie20

Cotton, D.R.E. and Alcock, I. (2012) Commitment to environmental sustainability in the UK student population. Studies in Higher Education, DOI:10.1080/03075079.2011.627423.

Deakin, M. (2006) Research Led Teaching: A review of two initiatives in valuing the link between teaching and research. Journal for Education in the Built Environment, 1(1), 73-93.

Durning, B. and Jenkins, A. (2005) Teaching/research relations in departments: the perspectives of built environment academics. Studies in Higher Education, 30(4), $407-$ 26.

Fry, H., Ketteridge, S. and Marshall, S. (2003) (eds.) A Handbook for Teaching and Learning in Higher Education: Enhancing academic practice, $2^{\text {nd }}$ Edn. London: Kogan Page.

Grant, K. and Wakelin, S.J. (2009) Re-conceptualising the concept of a nexus? A survey of 12 Scottish IS/IM academics' perceptions of a nexus between teaching, research, scholarship and consultancy. Teaching in Higher Education, 14, 133-146.

Griffiths, R. (2004) Knowledge production and the research-teaching nexus: the case of the built environment disciplines. Studies in Higher Education, 29(6), 709-726.

Hammersley, M. (1998) Reading Ethnographic Research: A Critical Guide, Longman, London.

Healey, M. (2005) Linking research and teaching exploring disciplinary spaces and the role of inquiry-based learning, in Barnett, R. (ed.) Reshaping the university: new relationships between research, scholarship and teaching, McGraw-Hill/Open University Press, pp. 67-78.

Healey, M., Jordan, F., Pell, B. and Short, C. (2010) The research-teaching nexus: a case study of students' awareness, experience and perceptions of research. Innovations in Education and Teaching International, 47(2), 235-46.

House of Commons (2009) Students and Universities. The Innovation, Universities, Science and Skills Committee report, London: The Stationery Office Limited. Jenkins, A., Blackman,T., Lindsay, R. O. and Paton-Saltzberg, R. (1998) Teaching and research: student perceptions and policy implications. Studies in Higher Education, 23(2), 127-141. 
This is an Accepted Manuscript of an article published by Taylor and Francis in Innovations in Education and Teaching International, available at:

http://www.tandfonline.com/doi/abs/10.1080/14703297.2013.847794?journalCode=riie20

Jenkins, A., Healey, M. and Zetter, R. (2007) Linking teaching and research in disciplines and departments. York: Higher Education Academy.

Jonassen, D.H. (1991). Objectivism verses constructivism: Do we need a new philosophical paradigm? Educational Technology Research \& Development, 39(3), 514.

Pan, W. and Allison, J. (2010) Exploring Project and Problem Based Learning in Environmental Building Education by integrating critical thinking. International Journal of Engineering Education, 26(3), 547-53.

Roberts, A. (2007) The link between research and teaching in architecture. Journal for Education in the Built Environment, 2(2), 3-20.

Strauss, A. and Corbin, J. (1998) Basics of Qualitative Research, London, Sage.

Tolley, G. (1983). Foreword, in The Higher Curriculum in Business Studies: Proceedings of a conference on values in business education, ed. D. Graves, p. 5, Higher Education Foundation, Chichester.

Visser-Wijnween, G.J., Van Driel, J.H., Van der Rijst, R.M., Verloop, N. and Visser, A. (2009) The relationship between academics' conceptions of knowledge, research and teaching - a metaphor study. Teaching in Higher Education, 14, 673-686.

Webster, C. (2002) Constructing the teaching-research link in the built environment disciplines. Exchange, 3, 15-16.

Yin, R.K. (2003). Case Study Research: Design and Methods. $3^{\text {rd }}$ ed. ThousandOaks: Sage.

Young, P. (2006) Out of balance: lecturers' perceptions of differential status and rewards in relation to teaching and research. Teaching in Higher Education, 11, 191-202. 